\title{
THE EFFECT OF PHYSICAL ACTIVITY ON THE DEPRESSION: A META-ANALYSIS
}

\section{Dyah Mubarokah Ahadiyati'), Didik Gunawan Tamtomo²), Vitri Widyaningsih ${ }^{3}$ )}

\author{
${ }^{1)}$ Master Program in Public Health, Universitas Sebelas Maret \\ 2)Masters Program in Family Medicine, Universitas Sebelas Maret
}

\begin{abstract}
Background: A recent report revealed that exercise help improve mood and reduce anxiety and depression. The links between depression, anxiety and exercise aren't entirely clear, but exercise and other forms of physical activity can ease symptoms of depression or anxiety. The purpose of this study was to investigate the effect of physical activity on the depression.

Subjects and Method: This was a meta-analysis and systematic review study. The study collected published articles from 2010 to 2020 in PubMed, Springer Link, and Google Scholar databases. We used "physical activity" AND "depression" OR "cross sectional" AND "depression" OR "physical activity" OR "adjusted odds ratio" keywords to search the articles. The inclusion criteria were full text, in English or Indonesia language, and using cross-sectional study. The selected articles were analyzed using RevMan 5.3.

Results: 6 articles from Brazil, China, United Kingdom, and Iran reported that physical inactivity increased depression $(\mathrm{aOR}=1.38$; $95 \% \mathrm{CI}=1.03$ to $1.85, \mathrm{p}=0.030)$ with $\mathrm{I}^{2}=86 \%$.

Conclusion: physical inactivity increase depression.

Keywords: physical activity, exercise, depression

\section{Correspondence:}

Dyah Mubarokah Ahadiyati. Masters Program in Public Health, Universitas Sebelas Maret. Jl. Ir. Sutami 36A, Surakarta 57126, Central Java. Email: mubarokah.dyah@gmail.com. Mobile: 085747333905 .
\end{abstract}

